\title{
Acaulospora paulinae, a new record of arbuscular mycorrhizal fungal species from Telangana state, India
}

\author{
K. Hari Prasad ${ }^{1}$, A. Hindumathi ${ }^{2}$, B. Bhadraiah ${ }^{3}$ \\ ${ }^{1}$ S.V. Government Arts \& Science College, Palem, Telangana, India \\ ${ }^{2,3}$ Applied Mycology and Molecular Plant Pathology Lab, Department of Botany, Osmania University, Hyderabad, India \\ *Corresponding Author: hariprasad.telangana@gmail.com
}

Available online at: www.isroset.org

Received: 10/Oct/2019, Accepted: 20/Oct/2019, Online: 31/Oct/2019

\begin{abstract}
Acaulospora paulinae was isolated from the rhizosphere soils of Setaria italica (Poaceae), Emilia sonchifolia and Vernonia cinerea (Asteraceae) from Nagarkurnool and Wanaparthy Districts, Telangana, India. The spores are globose to subglobose, 60-95 $\mu \mathrm{m}$ in diameter. Sometimes ovoid 60-70 X 80-95 $\mu \mathrm{m}$. Hyaline to sub hyaline or pale yellow. The spore wall composed of three layers. The surface of the middle layer is ornamented with evenly distributed pits 2.0-2.5 X 3.0-3.5 $\mu \mathrm{m}$. A. paulinae spores were found in sandy loam soils with decreasing spore numbers. A. paulinae is a characteristic member of the arbuscular mycorrhizal fungal communities in soils with $\mathrm{pH}$ 5.3-8.5 in sandy loam soils of Nagarkurnool and Wanaparthy Districts, Telangana, India.
\end{abstract}

Keywords-Acaulospora paulinae, Arbuscular mycorrhizal fungi, Glomeromycota, Rhizosphere, Acaulosporaceae, Spore morphology, Taxonomy.

\section{INTRODUCTION}

The genus Acaulospora belongs to Acaulosporaceae family of Diversisporales order of Glomeromycota. As on today we know 37 Acaulospora species with smooth surfaces and also with ornamentation of the outer spore wall [1]. The genus Acaulospora was described [2] and they also presented the first key for two species. Acaulospora laevis and Acaulospora elegans, the former produce spores with smooth surface and the later produce spores with an ornamented surface. The genus Acaulospora spores produced singly in the soil and develop laterally from the neck of sporiferous saccule [3]. The mycorrhizae of Acaulospora spp. consist of arbuscules, irregular and knobby vesicles and straight and coiled intraradical hyphae [4]. Schenck et al [5] presented the key to the ornamented species of Acaulospora. Oehl et al [6] presented latest key to the species of Acaulospora. We conducted a field survey on arbuscular mycorrhizal fungal association with Setaria italica (Poaceae), Emilia sonchifolia, and Vernonia cinerea (Asteraceae). These three plants showed the association of Acaulospora paulinae from Nagarkurnool and Wanaparthy Districts, Telangana, India.

\section{RELATED WORK}

A. paulinae was reported in grasslands and arable lands of Poland [7]. A. paulinae reported frequently in grasslands and arable lands of the upper Rhine lowland in France, Germany and Switzerland [8].

\section{METHODOLOGY}

Isolation and identification of AM Fungal spore:

Spores and sporocarps of AM fungi were isolated by using the wet sieving and decanting method [9]. AM fungal spore identification and their morphological characters were determined and analyzed qualitatively [10] and the websites of the International collection of vesicular and AM fungi (http://invam.wvu.edu/; $\quad$ http://www.zor.zut.edu.pl/ Glomeromycota).

\section{RESULTS AND DISCUSSION}

AM association and distribution: This study was conducted in two districts viz., Nagarkurnool (16019'47" N 78016'33'” E) and Wanaparthy (16018'57' N 780 02'24” E) Districts of Telangana, India. Acaulospora paulinae has been recorded from these two districts. A. paulinae associated with Setaria italica, Emilia sonchifolia and Vernonia cinerea.

Morphological Analysis: Acaulospora paulinae, Blaszk.

Spore description: Spores single in the soil and develop laterally on the neck of a sporiferous saccule, hyaline to pale 
yellow, globose to sub globose, $60-95 \mu \mathrm{m}$ in diam. Sometimes ovoid 60-70 X 80-95 $\mu \mathrm{m}$.

Spore wall: Spore wall composed of three layers (Swl1-3). L1 evanescent, hyaline $0.5-0.8 \mu \mathrm{m}$ thick. L2 laminate, hyaline to pale yellow $1.5-2.5 \mu \mathrm{m}$ thick, ornamented with evenly distributed pits 2.0-2.5 X 3.0-3.5 $\mu \mathrm{m}$ diam. L3 flexible, hyaline $<0.5 \mu \mathrm{m}$ thick, tightly adherent to $\mathrm{L} 2$.

Germination wall: Germination wall two layers (Gw1, Gw2). Gw1 flexible, hyaline, bi layered (Gw1L1, Gw1L2). Gw2 plastic, hyaline, bi layered (Gw2L1, Gw2L2). Sporiferous saccule hyaline, globose to sub globose, collapsing at maturity and leaving a cicatrix, 6-9 $\mu \mathrm{m}$ diam. at the point of spore attachment.

Key to Acaulospora spp. with ornamented outer spore wall: Below we present Oehl et al (2006) key, to help to distinguish the spores with depressions (pits) or cerebriforme folds of Acaulospora spp.

1. Spores with depressions (pits) or cerebriforme folds

1a. Spores with pits. 2

1b. Spores with cerebriforme folds - A.rehmii

2. Spores formed singly in soil, not in sporocarps...3

3a. Pits of regular round shape.....4

3b. Pits of irregular shape - A. scrobiculata, A. lacunosa.

4a. Spores with regular round pits, spores regularly $<100 \mu \mathrm{m}$ diam.....5

4 b. Spores with regular round pits, spores regularly $>100 \mu \mathrm{m}$ diam- $A$. foveata.

5a. Spores hyaline, sub

hyaline.............6

5b. Spores yellow to Orange brown- $A$. alpina.
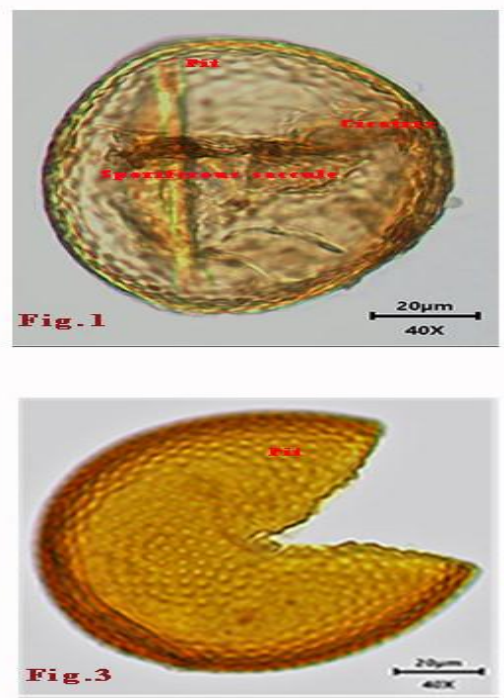

6a. Spore hyaline to sub hyaline, concave round pits of widest diameter $<3.5 \mu \mathrm{m}-$ A. Pauline 6b. Spore hyaline to sub hyaline, concave round pits of widest diameter $>3.5 \mu \mathrm{m}-$ A. undulata

\section{CONCLUSION}

Acaulospora paulinae spores were identified in the rhizosphere soils of Setaria italica, Emilia sonchifolia, and Vernonia cinerea collected from Nagarkurnool (site 1) and Wanaparthy (Site 2). Site 1(Nagarkurnool) identified spore has shown (Fig. 1 and 2) sub hyaline, ovoid shape $89.53 \mu \mathrm{m}$ diam. spore wall (L2) ornamented with evenly distributed pits 3.15-3.35 $\mu \mathrm{m}$ diam. Site 2 (Wanaparthy) identified spore has shown (Fig. 3 and 4) pale yellow, globose to sub globose shape $92.90 \mu \mathrm{m}$ diam. spore wall (L2) ornamented with evenly distributed pits 2.69-3.09 $\mu \mathrm{m}$ diam. All the morphological characters of the A. paulinae were well fitted according to Oehl et al keys for the identification of the spore. In the present study, A. paulinae spores were found in sandy loam soils with fewer spore numbers. A. paulinae and A. undulata spores are similar in size and colour. Examination of spores of these fungi under compound microscope readily separate them. A. paulinae has three layered spore wall and two layered germination walls, whereas the spore of $A$. undulata consists of only a two layered spore wall and one layered germination wall [11].

\section{ACKNOWLEDGMENT}

I would like to thank Southern Eastern Regional Office, Hyderabad for sanctioning minor research project, which has helped me complete the research work and also strengthen lab facilities in Government degree college.
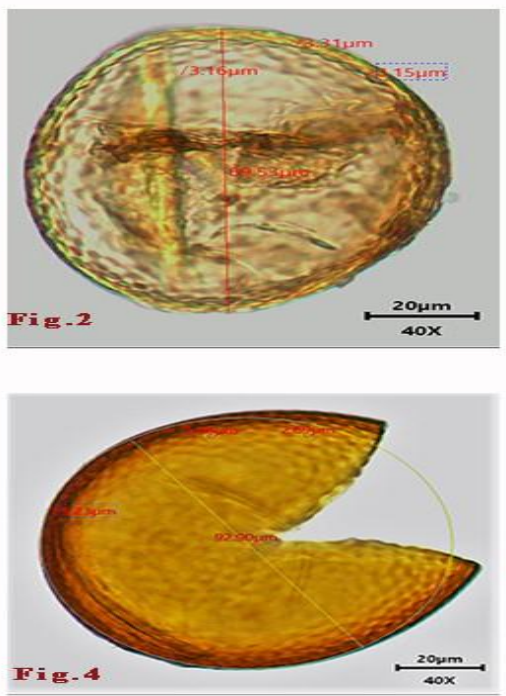

Fig. 1 and 2 are showing ovoid Acaulospora paulinae spore in Vernonia cinerea.

Fig. 3 and 4 are showing globose Acaulospora paulinae spore in Emilia sonchifolia and Setaria italica. 


\section{REFERENCES}

[1]. A. Schüßler and C. Walker, "The Glomeromycota: A Species List with New Families and New Genera". Schüßler, A., Walker, C., Gloucester, published in libraries at Royal Botanic Garden Edinburgh, Kew, Botanische Staatssammlung Munich, and Oregon State University, 2010.

[2]. J.W. Gerdemann and J.M. Trappe, "The Endogonaceae in the Pacific Northwest." Mycologia Memoir No.5. 76pp. 1974.

[3]. J. B. Morton and G. L. Benny, "Revised classification of arbuscular mycorrhizal fungi (Zygomycetes): a new order, Glomales, two new suborders, Glomineae and Gigasporineae, and two new families, Acaulosporaceae and Gigasporaceae, with an emendation of Glomaceae". Mycotaxon 37, pp. 471491, 1990.

[4]. J. B. Morton, "International Culture Collection of Arbuscular and Vesicular-Arbuscular Mycorrhizal Fungi. West Virginia University." 2000.

[5]. N.C. Schenck, J.L. Spain, E. Sieverding and R.H. Howler, "Several new and unreported vesicular arbuscular mycorrhizal fungi (Endogonaceae) from Colombia." Mycologia 76, pp. 685 . 699. 1984

[6]. F. Oehl, Z. Sýkorová, D. Redecker and A. Wiemken, "Acaulospora alpina, a new arbuscular mycorrhizal fungal species characteristic for high mountainous and alpine regions of the Swiss Alps." Mycologia 98, pp. 286-294. 2006.

[7]. J. Blaszkowski, "The occurrence of arbuscular fungi and mycorrhizae (Glomales) in plant communities of maritime dunes and shores of Poland." Bull. Pol. Ac. Sci. Biol. Sci. 41, 377-392. 1993a.

[8]. F. Oehl, E. Sieverding, P. Mader, D. Dubois, K. Ineichen, T. Boller and A. Wiemken, "Impact of long-term conventional and organic farming on the diversity or arbuscular mycorrhizal fungi." Oecologia. 138, pp. 574-583. 2004.

[9]. J. W. Gerdemann and T. H. Nicolson, "Spores of mycorrhizal Endogone extracted from soil by wet sieving and decanting." Trans. Brit. Mycol. Soc. 46, pp. 235-244.1963.

[10]. N.C. Schenck and Y. Perez, "Manual for the Identification of VA Mycorrhizal Fungi." Synergistic Publications, Gainesville, Florida, USA. pp 283. 1990.

[11].E. Sieverding, "Two new species of vesicular arbuscular mycorrhizal fungi in the Endogonaceae from tropical high lands of Africa." Angew. Bot. 62, pp. 373-380. 1988. 